\title{
ФОРМУВАННЯ ГАЛУЗЕВОЇ РАМКИ КВАЛІФІКАЦІЙ У ГАЛУЗІ ЗНАНЬ «ВОЕННІ НАУКИ, НАЦІОНАЛЬНА БЕЗПЕКА, БЕЗПЕКАДЕРЖАВНОГО КОРДОНУ
}

У статті розглянуто теоретичні аспекти побудови та формування галузевої рамки кваліфікачій у галузі знань «Воєнні науки, начіональна безпека, безпека державного кордону», проаналізовано та надано пропозииї щцодо внесення змін до відповідної нормативно-правової бази.

Ключові слова: галузева рамка кваліфікацій; національна рамка кваліфікацій; кваліфікаційні вимоги; професійні стандарти; компетентність; професія; стандарти вищої освіти.

Постановка проблеми: Досвід застосування підрозділів і військових частин ЗС України під час проведення антитерористичній операції та операції Об'єднаних сил на Сході держави обумовлює необхідність проведення змін у системі вищої військової освіти. Зміни до законів України, які унормовують системні перетворення військової освіти і підготовки військових фахівців, актуалізували набуття здобувачами вищої військової освіти нових освітніх та професійних компететностей. Проте, на сьогодні нормативно не врегульовано тлумачення щодо спеціальностей - «державна безпека»; «військове управління»; «національна безпека» та «безпека державного кордону», без яких не можливо чітко визначитися із компетенціями та вимогами до визначених спеціальностей.Також не визначено поняття професії у військовій сфері, національній безпеці та безпеці державного кордону.

Аналіз останніх досліджень і публікацій: Дослідження спирається на аналіз вимог нормативно-правових документів, що регулюють формування галузевої рамки кваліфікацій у галузі знань «Воєнні науки, національна безпека, безпека державного кордону»[1-3]. Дослідження теоретичних питань, пов'язаних 3 формуванням галузевої рамки кваліфікацій у галузі знань «Воєнні науки, національна безпека, безпека державного кордону», не отримало належного висвітлення в наукових джерелах і залишається актуальним на сьогоднішній день.

Мета статті полягає у визначенні етапів та змісту процесу формування галузевої рамки кваліфікацій у галузі знань «Воєнні науки, національна безпека, безпека державного кордону».

Методи дослідження: системний аналіз і синтез, індукція і дедукція, порівняння, класифікація, узагальнення та систематизація

Виклад основного матеріалу. Відповідно до зовнішньополітичного курсу України - вступ до Свропейського Союзу та НАТО, - зусилля підготовки військових кадрів також направлені на впровадження вимог освіти розвинутих 
країн Європи. На сьогодні, відповідно до вимог Європейського Союзу опрацьовано та діє теоретичний концепт військової освіти, на основі якого здійснюється підготовка фахівців для сектору безпеки і оборони держави, розвиваються відповідні положення, які охоплюють законодавчі та нормативні акти $Є С$ та України, Свропейську рамку кваліфікацій для навчання військових фахівців впродовж життя та Національну рамку кваліфікацій. Водночас, відповідно до вимог законодавства України та вимог нормативних актів СС, потрібно сформувати та ввести в дію Галузеву рамку кваліфікацій (ГРК) у відповідних галузях знань, спільні європейські та державні стандарти 3 підготовки фахівців у військовій сфері та сферах безпеки і оборони, профілі професійних компетентностей фахівців з військових спеціальностей[4]. ГРК має розроблятись відповідно до вимог Законів України «Про освіту» [1] та «Про вищу освіту»[2] затверджено постановою Кабінету Міністрів України від 23 листопада 2011 року №1341(із змінами від 12 червня 2019 року №509) Національну рамку кваліфікацій [3].

Національна рамка кваліфікацій - це системний i структурований за компетентностями опис ії рівнів. Національна рамка кваліфікацій призначена для використання органами державної влади та органами місцевого самоврядування, установами та організаціями, закладами освіти, роботодавцями, іншими юридичними та фізичними особами 3 метою розроблення, ідентифікації, співвіднесення, визнання, планування і розвитку кваліфікацій.

Національна рамка кваліфікацій грунтується на європейських і національних стандартах та принципах забезпечення якості освіти, враховує вимоги ринку праці до компетентностей працівників та запроваджена 3 метою гармонізації норм законодавства у сферах освіти і соціально-трудових відносин, сприяння національному та міжнародному визнанню кваліфікацій, здобутих в Україні, налагодження ефективної взаємодії сфери освіти і ринку праці.

Також відповідно до постанови Кабінету Міністрів України від 29 квітня 2015 р. № 266 «Про затвердження переліку галузей знань і спеціальностей, за якими здійснюється підготовка здобувачів вищої освіти» затверджено галузь знань «Воєнні науки, національна безпека, безпека державного кордону»[5] із відповідним шифром 25 , кодами та найменуваннями спеціальностей, а саме:

251 - державна безпека;

252 - безпека державного кордону;

253 - військове управління (за видами збройних сил);

254 - забезпечення військ (сил);

255 - озброєння та військова техніка;

256 - національна безпека (за окремими сферами забезпечення і видами діяльності).

Визначена галузь знань споріднює спеціальності у військовій сфері та у сферах, що належать до безпеки і оборони держави.

Відповідно до вимог постанови Кабінету Міністрів України від 23 листопада 2011 року №1341(із змінами від 12 червня 2019 року №509)[3] повинно бути розроблено ГРК, у якій конкретизується опис їх рівнів у термінах 
компетентностей, що характерні для кваліфікацій певної галузі знань та/або виду економічної діяльності. Рівні Галузевої рамки кваліфікацій мають співвідноситися 3 відповідними рівнями Національної рамки кваліфікацій. Галузева рамка кваліфікацій повинна бути затверджена Кабінетом Міністрів України, таким чином вона є нормативним актом для всіх вищих військових навчальних закладів.

Водночас Законом України «Про освіту»[1] визначено, що кваліфікація - це визнана уповноваженим суб'єктом та засвідчена відповідним документом стандартизована сукупність здобутих особою компетентносте й (результатів навчання), але Законом України «Про вищу освіту» [2] визначено, що кваліфікація -це офіційний результат оцінювання і визнання, який отримано, коли уповноважена установа встановила, що особа досягла компетентностей (результатів навчання) відповідно до стандартів вищої освіти, що засвідчується відповідним документом про вищу освіту. При цьому професійна підготовка визначається як здобуття кваліфікаціїза відповідним напрямом підготовки або спеціальністю. Професійна підготовка являє собою цілеспрямований процес навчання наявних (працюючих) і потенційних (студентів, курсантів) працівників професійних знань та вмінь з метою набуття навичок, необхідних для виконання певних видів робіт.

Відповідно до вимог Класифікатора професій (ДК 003:2010), затвердженого наказом Міністерства економічного розвитку і торгівлі України від 15 лютого 2019 року № 259 [6] не визначено професії для військовослужбовців. Хоча відповідно до вимог законодавства кваліфікація - це здатність виконувати завдання та обов'язки відповідної роботи. У дипломі бакалавра (магістра) чи іншому документі про професійну підготовку кваліфікація визначається через назву професії (інженер-механік, економіст, токар, секретар-стенографіст тощо).

У свою чергу професія - це здатність виконувати подібні роботи, які вимагають від особи певної кваліфікації. Робота є статистичною одиницею, що

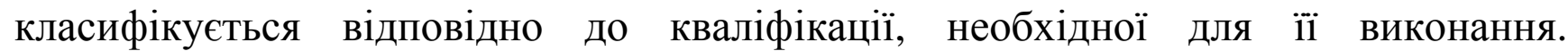
Кваліфікація визначається рівнем освіти та спеціалізацією. Необхідний рівень освіти досягається завдяки реалізації освітніх, освітньо-професійних та освітньонаукових програм підготовки і має в цілому відповідати колу та складності професійних завдань та обов'язків. Спеціалізація ж пов'язана як з необхідною галуззю знань, використовуваними інструментами чи устаткуванням, так і 3 продукцією, яка виробляється, або надаваними послугами і відповідає певною мірою деталізованому колу професійних завдань та обов’язків.

Варто зауважити, що відповідно до вимог Закону України «Про військовий обов’язок і військову службу» від 25.03.1992 № 2232-ХІІ[7] військова служба $є$ державною службою особливого характеру, яка полягає у професійній діяльності придатних до неї за станом здоров'я і віком громадян України, пов'язаній із захистом Вітчизни. Час проходження військової служби зараховується громадянам України до їх страхового стажу, стажу роботи, стажу роботи за спеціальністю, а також до стажу державної служби. Таким чином професію військового необхідно дорівнювати професії державного службовця, тому 
вважаємо за доцільне внесення до Класифікатору професій відповідних змін щодо рівнозначності та співвідношення військових професій до державної служби.

Ураховуючи наведене вище, для формування й побудови Галузевої рамки необхідно чітко визначитися 3 етапами їі формування. Етапи побудови та формування Галузевої рамки кваліфікацій можна представити блок схемою (рис. 1).

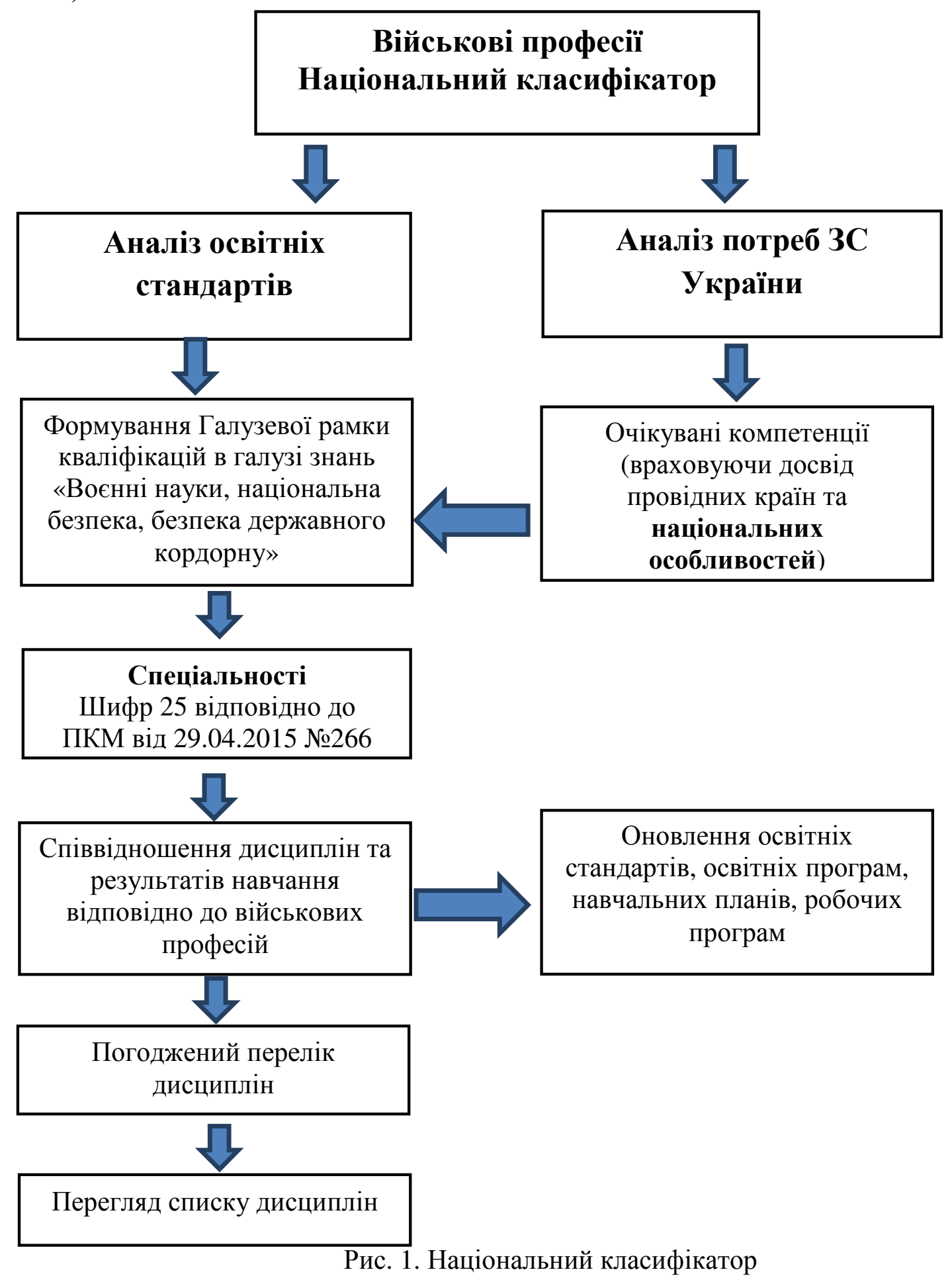

Побудова Галузевої рамки кваліфікацій починається з визначення професій, які є чи потрібні для військової служби у Збройних Силах та інших військових формуваннях України. На сьогодні відповідно до Класифікатора професій, 
затвердженими наказом Міністерства економічного розвитку і торгівлі України від 15 лютого 2019 року № 259[7]не визначено професії у військовій сфері, національній безпеці та безпеці державного кордону. Наказами відповідних міністерств та відомств, в підпорядкуванні яких $\epsilon$ військові формування, затверджені відповідні переліки посад.

Для подальшої роботи 3 побудови Галузевої рамки необхідно вивчити світовий та власний досвід та провести порівняльний аналіз, це дасть змогу більш якісно визначитися із обліком професій та кваліфікацій у військовій сфері. При цьому одним з головних чинників під час формування Галузевої рамки також $\epsilon$ аналіз потреб Збройних Сил та інших військових формувань у тих чи інших спеціалістах, фахівцях та професіях. Наступним етапом є визначення компетенції до професій та спеціалістів військової служби, визначається перелік дисциплін та кількість кредитів для їх опанування. У результаті формується Галузева рамка кваліфікацій та вноситься на розгляд Кабінету Міністрів України для затвердження.

Після затвердження Галузевої рамки у разі необхідності до існуючих стандартів, навчальних планів, робочих програм вносяться відповідні зміни (рис.2).

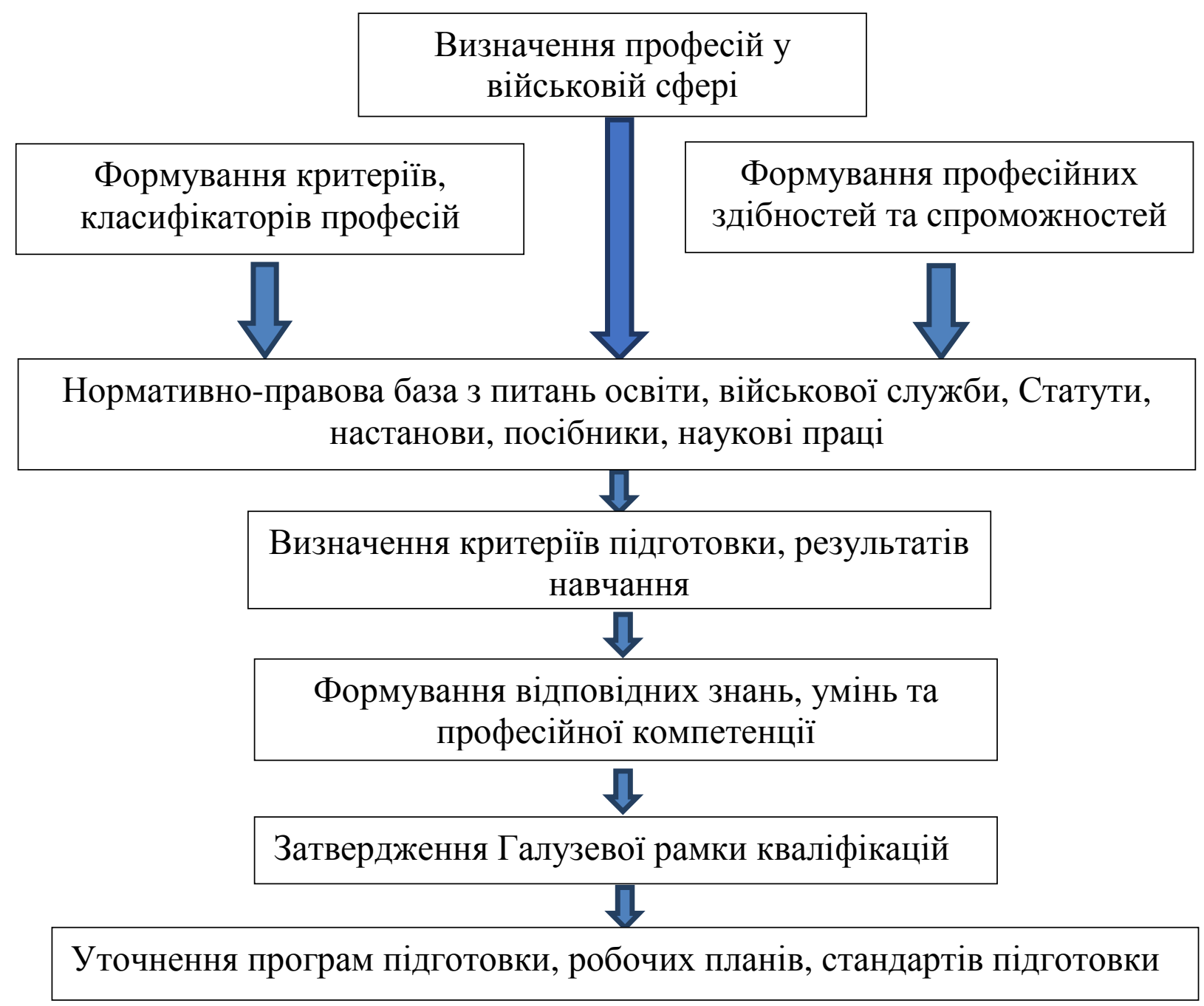

Рис. 2. Етапи формування галузевої рамки кваліфікацій 
Аналіз стандартів вищої освіти за спеціальностями у галузі знань «Військові науки, національна безпека, безпека державного кордону» вказує, що на сьогодні відсутній єдиний підхід до цілій, методів та кінцевих результатів підготовки військовослужбовців Збройних Сил та інших військових формувань, утворених відповідно до законів України. Розроблені стандарти за відповідними спеціальностями у кожному із силових відомств різняться по суті та структурно не пов'язані між собою. Особливо це стосується підготовки офіцерських кадрів оперативного рівня. Це є проблемою, яку необхідно вирішити у тому числі й під час підготовки ГРК, оскільки ця проблема безпосередньо стосується питань військової освіти та підготовки військових фахівців, у певних питаннях унеможливлюючи проведення подальшого реформування всієї системи вищої військової освіти та професійної підготовки за стандартами НАТО.

Так, на тактичному рівні підготовки офіцерських кадрів такий підхід обумовлений специфікою підготовки спеціалістів кожного силового відомства, водночас основи та стандарти військової підготовки для всіх збройних формувань, особливо, що входять до сил оборони, повинні бути єдиними. На сьогодні спорідненість в програмах підготовки офіцерів тактичного рівня спостерігається лише між військовими інститутами Збройних Сил та Національної гвардії України. Військовослужбовці Державної прикордонної служби України за військовими дисциплінами мають лише базову підготовку для офіцерів запасу. Офіцери Служби безпеки України проходять підготовку лише за вузькою спеціальністю, а Управління державної охорони України - лише за напрямком своєї діяльності. Водночас всі військовослужбовці інших військових формувань по закінченню вищих навчальних закладів профільних відомств отримують первинні офіцерські звання та в подальшому маючи лише базову (для офіuерів запасу) військову підготовку продовжують військову службу та просуваються по службі не маючи певних та достатніх знань, що необхідні для офіцерів оперативного та стратегічного рівнів освіти.

Магістерський (оперативний) рівень підготовки військових фахівців має за мету підготовку висококваліфікованих воєнних кадрів для органів управління силових відомств та повинен бути єдиним. Офіцери оперативного рівня всіх військових формувань, особливо сектору оборони, повинні мати знання з питань оперативного планування спільних операцій, порядок взаємодії та виконання завдань під час спільних операцій кожним із силових відомств, чітко розуміти роль і місця органів військового управління кожного військового формування. Водночас, на сьогодні підготовка офіцерських кадрів оперативного рівня силових відомств України здійснюється за різними програмами та в окремих випадках фактично за тією ж самою, що й тактичного рівня.

Уніфікація вищої військової освіти, особливо на оперативному рівні, повинна створити умови для поєднання стандартів підготовки офіцерських кадрів Збройних Сил та інших військових формувань, утворених відповідно до законів України. Така підготовка повинна проводитися на базі одного чи двох спеціалізованих університетів за відповідною єдиною програмою для всіх офіцерських кадрів сектору оборони, що розглядаються або прагнуть бути 
керівниками оперативного рівня. Це надасть позитивні результати у порядку спільних підходів до розуміння організації оборони держави.

3 метою узагальнення основних компетентностей для кваліфікацій Галузі знань «Воєнні науки, національна безпека, безпека державного кордону» розпочато роботу зі створення Галузевої рамки кваліфікацій, де потрібно визначити основні вимоги до інтегральних, загальних й фахових компетентностей для спеціалізації у військовій сфері.

На основі затвердженої Галузевої рамки потрібно розробити (уточнити) стандарти вищої освіти для кожної спеціалізації. Стандарти вищої освіти за кожною спеціальністю розробляє центральний орган виконавчої влади у сфері освіти і науки з урахуванням пропозицій галузевих державних органів, до сфери управління яких належать заклади вищої освіти, і галузевих об'єднань організацій роботодавців та затверджує їх за погодженням із Національним агентством із забезпечення якості вищої освіти. Фактично нові стандарти вищої освіти $€$ наступним поколінням стандартів і замінюють собою Галузеві стандарти вищої освіти (ГСВО), які розроблялись у 2002 - 2014 роках відповідно до діючого на той час законодавства. Сучасні стандарти базуються на компетентному підході і поділяють філософію визначення вимог до фахівця, закладену в основу Болонського процесу та в міжнародному Проекті Європейської Комісії «Гармонізація освітніх структур в Європі» (Tuning EducationalStructuresinEurope, TUNING).

Відповідно до вимог Закону України «Про вищу освіту» Науково-методична рада (НMP) Міністерства освіти і науки України (МOH) за участю Національного агентства із забезпечення якості вищої освіти (НАЗЯВО) розробляє методологію, методичні рекомендації щодо розроблення стандартів вищої освіти, а науковометодичні комісії (НМК) здійснюють розроблення цих стандартів й на сьогодні у Галузі знань «Воєнні науки, національна безпека, безпека державного кордону» розроблені стандарти вищої освіти за спеціальностями:

253 військове управління (за видами збройних сил) за рівнями вищої освіти бакалавр та магістр (накази Міністерства освіти і науки України від 29.10.2018 №1168 та 24.05.2019 №724);

252 безпека державного кордону за рівнями вищої освіти бакалавр та магістр (накази Міністерства освіти і науки України від 12.12.2018 №1384 та від 04.03.2020 №379);

254 забезпечення військ (сил) за рівнем вищої освіти бакалавр та магістр (наказ Міністерства освіти і науки України від 12.12.2018 №1385 та від 30.04.2020 №582);

255 озброєння та військова техніка за рівнем освіти бакалавр та магістр (наказ Міністерства освіти і науки України від 05.12.2018 №1341 та від 30.04.2020 №583).

Проте, не зважаючи на проведену роботу, поки що не розроблено та не введено в дію відповідними наказами Міністерства освіти і науки України стандарти вищої освіти за спеціальностями 251 державна безпека та 256 національна безпека (за окремими сферами забезпечення і видами діяльності). 


\section{Висновки та перспективи подальших наукових досліджень.}

Запровадження галузевої рамки кваліфікацій у систему підготовки військовослужбовців сектору безпеки i оборони на національному рівні, забезпечує не тільки чітку структурованість, можливість застосування високоефективних практик країн Європейського та Євроатлантичного союзів, а також значне посилює стандарти безпеки держави, сприяє підвищенню iii обороноздатності й узгодженості дій всіх елементів сектору безпеки і оборони.

У подальшому планується розробити державний стандарт (Галузева рамка кваліфікацій) освітньо-професійної діяльності для галузі знань “Воєнні науки, національна безпека, безпека державного кордону” для кожного рівня підготовки за відповідною спеціалізацією згідно Національної рамки кваліфікацій та стандартів НАТО. Це буде ще одним кроком щодо досягнення операційної сумісності Збройних Сил України та збройних сил країн-членів НАТО 3 підготовки військових фахівців.

\section{ЛІТЕРАТУРА}

1. Закон України “Про освіту” від 05 вересня 2017 р. № 2145-VIII. [Електронний ресурс].Режим доступу: https://zakon.rada.gov.ua/laws/show/2145-19

2. Закон України “Про вищу освіту” від 01 липня 2014 p. № 1556-VII. [Електронний ресурс]. - Режим доступу: http://zakon.rada.gov.ua

3. Постанова Кабінету Міністрів України від 23 листопада 2011 року №1341“Про затвердження Національної рамки кваліфікації” (із змінами, внесеними згідно 3 постановою Кабінету Міністрів України від 12 червня 2019 р. № 1341). [Електронний ресурс]. - Режим доступу: http://zakon.rada.gov.ua.

4.Рибчук О.О. Структура та зміст фахової компетентності викладачів вищих військових навчальних закладів. Нові технології навчання: наук.-метод. Зб. Інститут інноваційних технологій і змісту освіти МОН України. Київ, 2016. С. 190-196.

5. Постанова Кабінету Міністрів України від 29квітня 2015 року № 266 "Про затвердження переліку галузей знань і спеціальностей, за якими здійснюється підготовка здобувачів вищої освіти" [Електронний ресурс]. - Режим доступу: http://zakon.rada.gov.ua

6. Класифікатора професій (ДК 003:2010), затвердженого наказом Міністерства економічного розвитку і торгівлі України від 15 лютого 2019 року № 259[Електронний ресурс]. - Режим доступу: http://zakon.rada.gov.ua

7. Закон України “Про військовий обов’язок і військову службу” від 25.03.1992 № 2232XII [Електронний ресурс]. - Режим доступу: http://zakon.rada.gov.ua

\section{REFERENCES}

1. Zakon Ukrayiny "Pro osvitu” vid 05 veresnya 2017 r. № 2145-VIII. [Elektronnyy resurs].Rezhym dostupu: https://zakon.rada.gov.ua/laws/show/2145-19.

2. Zakon Ukrayiny "Pro vyshchu osvitu" vid 01 lypnya 2014 r. № 1556-VII. [Elektronnyy resurs]. - Rezhym dostupu: http://zakon.rada.gov.ua.

3. Postanova Kabinetu Ministriv Ukrayiny vid 23 lystopada 2011 roku №1341“Pro zatverdzhennya Natsional $\square$ noyi ramky kvalifikatsiyi” (iz zminamy, vnesenymy z·hidno z postanovoyu Kabinetu Ministriv Ukrayiny vid 12 chervnya 2019 r. № 1341). [Elektronnyy resurs]. - Rezhym dostupu: http://zakon.rada.gov.ua.

4. Rybchuk O.O. Struktura ta zmist fakhovoyi kompetentnosti vykladachiv vyshchykh viys $\square$ kovykh navchal $\square$ nykh zakladiv. Novi tekhnolohiyi navchannya: nauk.-metod. Zb. Instytut innovatsiynykh tekhnolohiy i zmistu osvity MON Ukrayiny. Kyyiv, 2016. S. 190-196. 
5. Postanova Kabinetu Ministriv Ukrayiny vid 29kvitnya 2015 roku № 266 “ Pro zatverdzhennya pereliku haluzey znan $\square$ i spetsial $\square$ nostey, za yakymy zdiysnyuyet $\square$ sya pidhotovka zdobuvachiv vyshchoyi osvity" [Elektronnyy resurs]. - Rezhym dostupu: http://zakon.rada.gov.ua

6. Klasyfikatora profesiy (DK 003:2010), zatverdzhenoho nakazom Ministerstva ekonomichnoho rozvytku i torhivli Ukrayiny vid 15 lyutoho 2019 roku № 259[Elektronnyy resurs]. Rezhym dostupu: http://zakon.rada.gov.ua.

7. Zakon Ukrayiny "Pro viys $\square$ kovyy obov $\square$ yazok i viys $\square$ kovu sluzhbu" vid 25.03.1992 № 2232-XII [Elektronnyy resurs]. - Rezhym dostupu http://search.ligazakon.ua/ 1_doc2.nsf/link1/ed_2004_06_15/T223200.html.

\section{PЕЗЮМЕ}

Олег Митягин, кандидат исторических наук Национальный университет обороны Украины имени Ивана Черняховского

\section{Формирование отраслевой рамки квалификаций в отрасли знаний «Военные науки, национальная безопасность, безопасность государственной границы»}

Исследованы вопросы формирования отраслевой рамки квалификащии в отрасли знаний «Военные науки, национальная безопасность, безопасность государственной границы», проанализированы и разработаны предложения для внесения изменений в соответствующую нормативно-правовую базу.

Ключевые слова: отраслевая рамка квалификаций; наџиональная рамка квалификачий,; квалификационные требования; професиональные стандарты; компетентность; профессия; стандарты висшего образования.

\section{SUMMARY}

Oleh Mitiagin,

$\mathrm{PhD}$ (historicals ciences)

National Defense University of Ukraine named after Ivan Chernyakhovskyi

\section{The branch framework of qualifications in branch of knowledge "Military sciences, national safety, safety of state board" forming}

Introduction. Reforming of the military education system requires the development and implementation of a number of legal documents governing the activities of higher education institutions, the system of professional training and retraining of military specialists. Among the main legal documents is the development of the Sectoral Framework of Qualifications in the field of knowledge "Military Sciences, National Security, State Border Security.

Purpose. The purpose of the article is to determine the stages and content of the process of formation of the sectoral framework of qualifications in the field of knowledge "Military Sciences, National Security, State Border Security".

Methods. The system of general scientific and special methods of theoretical and empirical research (analysis of scientific literature, systematization and generalization of materials, logic and comparative, content analysis) was used in order to realize the article purpose.

Results. The issues of formation of the sectoral qualification framework in the field of knowledge "Military Sciences, National Security, State Border Security" have been investigated, proposals have been analyzed and developed for amending the relevant legal framework.

Content. Analysis of higher education standards in the field of knowledge "Military Sciences, National Security, State Border Security" indicates that today there is no single approach to the goals, 
methods and results of training of servicemen of the Armed Forces and other military formations formed in accordance with the laws of Ukraine. The standards developed for the respective specialties in each of the law enforcement agencies differ in essence and are not structurally related. This is especially true of the training of operational-level officers. This is a problem that needs to be addressed, including in the development of the Sectoral Qualifications Framework, as it is directly related to military education and training, in some respects preventing further reform of the entire NATO higher education and training system.

Conclusion. The article defined the stages and content of the process of formation of the sectoral framework of qualifications in the field of knowledge "Military Sciences, National Security, State Border Security".

Key words: sectoral qualifications framework; national qualifications framework; qualification requirements; professional standards; competence; profession; higher education standards. 